\title{
Pulmonary Inflammation Induced by Incomplete or Inactivated Adenoviral Particles
}

\author{
RONALD D. MCCOY, ${ }^{1}$ BEVERLY L. DAVIDSON, ${ }^{2}$ BLAKE J. ROESSLER,${ }^{3}$ GARY B. HUFFNAGLE, ${ }^{1}$ \\ SONIA L. JANICH, ${ }^{3}$ TIMOTHY J. LAING, ${ }^{3}$ and RICHARD H. SIMON ${ }^{1}$
}

\begin{abstract}
One of the major obstacles to pulmonary-directed gene therapy using adenoviral vectors is the induction of inflammation. We investigated whether the adenoviral particles that constitute the initial inoculum can serve as an inflammatory stiunulus, independent of their ability to express genes that they contain. Viral particles were prepared that are defective in gene expression by (i) isolating particles that have imcomplete genomes by selecting those that have buoyant densities on $\mathrm{CsCl}$ density gradients lighter than complete viruses; and (ii) cross-linking viral DNA by exposure to ultraviolet light in the presence of 8-methoxypsoralen. The defective particles retained their icosahedral appearance when viewed by electron microscopy but lost their plaqueforming ability on 293 cells. High doses of intact, incomplete, or inactivated viral particles were instilled imtratracheally into CBA/J mice, and after 6 days the amount of inflammation was quantified by counting inflainmatory cells contained within lung tissue. We found that the inflammatory responses induced by the incomplete or inactivated viral vectors were quantitatively similar to those caused by intact, competent viral vectors. We conclude that high doses of adenoviral vectors that are used for gene therapy can induce pulmonary inflammation, independent of expressing the genes they contain.
\end{abstract}

\section{OVERVIEW SUMMARY}

The amount of pulmonary inflammation induced in mice by intratracheal administration of high doses of adenoviral vectors was compared to that induced by viral particles that lack the ability to express the genes that they contain. The number of inflammatory cells infiltrating the lung 6 days after particle administration was similar between animals receiving normal versus defective adenoviral particles.

\section{INTRODUCTION}

$\mathbf{P}$ ULMONARY INFLAMMATION complicates the use of recombinant adenoviruses as gene therapy vectors. Administrating high doses of adenoviral vectors to the airways of experimental animals causes pulmonary infiltrates consisting of macrophages and lymphocytes with neutrophils appearing transiently during the early stage (Ginsberg et al., 1991; Prince $e t$ al., 1993; Simon et al., 1993; Brody et al., 1994; Engelhardt et al., 1994; Yang et al., 1994; Yei et al., 1994). Pulmonary infiltrates have also been reported in a patient who received a relatively high dose of an adenovirus-based vector during a gene therapy trial for treatment of cystic fibrosis (Crystal et al., 1994). The causes of the pulmonary inflammation induced by adenoviral vectors are being actively investigated. Elevated levels of the inflammatory cytokines, interleukin-1 (IL-1), IL-6, and tumor necrosis factor- $\alpha$, have been detected following airway administration of either wild-type or recombinant adenoviruses (Ginsberg et al., 1991; Crystal et al., 1994). In many animal models, the humoral immune system is activated, leading to generation of antiviral antibodies (Yei et al., 1994; Zabner et al., 1994). Cytotoxic T lymphocytes accumulate in the lung as part of a $T_{H} 1$ response mediated by helper $T$ cells that release IL-2 and interferon- $\gamma$ (Engelhardt $e t$ al., 1994; Yang et al., 1994, 1995). Expression of adenovirus-specific genes, despite the deletion of the E1 region, is thought to provide a stimulus that leads to the immune response. Manipulation of the

\footnotetext{
'Division of Pulmonary and Critical Care Medicine and ${ }^{3}$ Division of Rheumatology, Department of Internal Medicine, University of Michigan Medical Center, Ann Arbor, MI 48109-0360.

2Pulmonary Division, Department of Internal Medicine, University of Iowa, Iowa City, IA 52242.
} 
adenoviral genome that further reduces expression of adenoviral genes has been shown to decrease the pulmonary inflammatory reaction (Engelhardt et al., 1994; Yang et al., 1994).

Although residual expression of viral genes within transfected cells can contribute to the inflammatory response, an important stimulus may be supplied by the proteins contained in the adenoviral particles that serve as vehicles for gene delivery. In the present study, we determined whether expression of adenovirus-specific genes within target cells was required for pulmonary inflammation to occur following intratracheal administration. We did so by comparing the amount of inflammation caused by intact adenoviral vectors with that caused by vectors whose gene expression was impaired. For these studies, we used an adenoviral vector containing a marker gene consisting of a cDNA for human IL-1 receptor antagonist (IL-1ra), designated Ad.RSVIL-Ira. The availability of a sensitive and specific ELISA for IL-1ra protein provided a method to measure residual gene expression following in vivo delivery of defective viral particles. Importantly, IL-1ra could serve as a marker gene because we had previously found that the amount of inflammation induced by Ad.RSVIL-I ra following intratracheal delivery to mice did not differ from the amount caused by a recombinant adenovirus that contained no transgene expression cassette (McCoy et al., 1995).

\section{MATERIALS AND METHODS}

\section{Adenoviral vectors}

The construction and characterization of a recombinant adenoviral vector containing a human IL-1ra cDNA (Ad.RSVIL1ra) has been previously described by Roessler et al. (1995). Ad.RSVIL-1 ra has deletions in the E1A and E1B regions (map units 1-9), and in the E3 region (map units 83-85) that make it replication defective and provide adequate room for insertion of an expression cassette. The IL-1 ra expression cassette, which is inserted in the E1 position, consists of the Rous sarcoma virus (RSV) long terminal repeat (LTR) as promoter, a cDNA for human IL-1ra, and a transcription termination signal supplied by the simian virus-40 late gene polyadenylation sequence. Ad.RSVIL-I ra was propagated using the permissive 293 cell line and purified from cell lysates by centrifuging twice on $\mathrm{CsCl}$ density gradients. The band containing intact, complete viral particles was removed from the $\mathrm{CsCl}$ gradient and desalted on Sephadex G50 columns (Pharmacia, Uppsala, Sweden) with phosphate-buffered saline (PBS). The viral preparations were analyzed for their ability to form plaques on confluent 293 cell monolayers (Graham et al., 1977).

\section{Preparation of incomplete Ad.RSVIL-1ra particles}

Incomplete particles of Ad.RSVIL-Ira were isolated from the final $\mathrm{CsCl}$ density gradient that was used to prepare intact Ad.RSVIL-1ra (Burlingham et al., 1974; Toth et al., 1982; Morin and Boulanger, 1984). The visible band that formed above that containing the complete particles was removed by puncturing the lateral wall of the centrifuge tube at the appropriate site with an 18-gauge needle. The particle suspension that was aspirated from the gradient was desalted on a Sephadex G50 column with PBS.

\section{Inactivation of Ad.RSVIL-1 ra by psoralen/ultraviolet light treatment}

Ultraviolet light treatment in the presence of 8-methoxypsoralen was used to inactivate Ad.RSVIL-lra (Hudson et al., 1985; Cotten et al., 1992, 1994). One milliliter containing $3.8 \times$ $10^{12}$ particles of Ad.RSVIL-I ra in PBS was placed into a 35mm culture dish at $4^{\circ} \mathrm{C}$. 8-Methoxypsoralen (Sigma Chemical Co., St. Louis, MO) was dissolved in dimethylsulfoxide at 33 $\mathrm{mg} / \mathrm{ml}$ and added to the viral suspension to yield a final concentration of $330 \mu \mathrm{g} / \mathrm{ml}$. The plate was placed on a layer of chipped ice and exposed to ultraviolet $\mathrm{A}$ band light generated by an argon laser (Innova 328, Coherent Inc., Palo Alto, CA; spectral output $333,351.1$, and $363 \mathrm{~nm}$ ). Light was conducted through a fiber optic catheter (Forensic Optical Cable, Coherent Inc.) positioned $30 \mathrm{~cm}$ above the virus-containing culture dish so that the diameter of the beam matched that of the culture dish. The sample was exposed for $30 \mathrm{~min}$, resulting in an ultraviolet A dose of $180 \mathrm{~J} / \mathrm{cm}^{2}$. The plate was rotated periodically to maintain adequate cooling and insure even exposure of the particles. The inactivated particles were then passed over a Sephadex G-50 column that was equilibrated and eluted with PBS to remove free psoralen.

\section{Electron microscopy}

An aliquot of viral particles was fixed in $1 \%$ glutaraldehyde, $0.05 M$ cacodylate buffer $\mathrm{pH} 7.4$ for $10 \mathrm{~min}$ at room temperature. The solution was spread over 200-mesh carbon-coated grids (Electron Microscopy Sciences, Fort Washington, PA). After $10 \mathrm{~min}$, excess suspension was wicked off with filter paper. The grids were stained with $2 \%$ uranyl acetate for $1 \mathrm{~min}$, rinsed, and allowed to dry. The particles were viewed using a Philips CM-10 transmission electron microscope (Eindhoven, The Netherlands).

\section{Detection of adenoviral E2A protein by immunoelectrophoresis}

Monolayers of 293 cells in 60 -mm tissue culture dishes were rinsed twice with medium and overlaid with $2 \mathrm{ml}$ of medium containing viral particles at 5,000 particles per cell. After $4 \mathrm{hr}$ at $37^{\circ} \mathrm{C}$ in $5 \% \mathrm{CO}_{2} / 95 \%$ air, the medium was replaced with fresh containing $10 \%$ fetal bovine serum. After $20 \mathrm{hr}$, the cells were suspended by scraping, centrifuged at $1,000 \times g$ for 10 min, and suspended in buffer containing sodium dodecyl sulfate and $\beta$-mercaptoethanol. The proteins contained in the lysates were separated by electrophoresis on $8 \%$ polyacrylamide gels (Laemmli, 1970) and transferred electrophoretically to Immobilon-P membranes (Millipore Corp., Bedford, MA). The membranes were probed with a mouse monoclonal antibody against adenovirus E2A protein (clone B6-6-10; generously provided by Dr. Arnold J. Levine, Princeton University, Princeton, NJ) (Reich et al., 1983). The membranes were developed using a goat anti-mouse horseradish peroxidase-conjugated secondary antibody and a chemiluminescence detection system (ECL), both of which were obtained from Amersham Life Sciences (Arlington Heights, IL). The molecular weights of bands were measured by comparing the distances migrated with those of protein standards (New England Biolabs, Beverly, MA). 


\section{Intratracheal administration of viral particles to mice}

Specific pathogen-free, male, CBA/J mice that were 4-6 weeks old were purchased from Jackson Laboratories (Bar Harbor, ME). Each animal was anesthetized intraperitoneally with $0.2 \mathrm{mg} / \mathrm{gm}$ ketamine and positioned with its dorsal surface against a board that was tilted $45^{\circ}$ to the horizontal with its head up. The skin and connective tissue were incised overlying the cervical trachea, and $50 \mu \mathrm{l}$ of PBS, with or without viral particles, was slowly injected intratracheally using a Hamilton syringe (Reno, NV). The incision was closed with a surgical clip, and the animal returned to its cage. After 6 days, each animal was anesthetized again with ketamine and sacrificed by exsanguination. The lungs were perfused free of blood by slowly injecting $3 \mathrm{ml}$ of PBS into the right ventricle with the solution being allowed to exit through a vent in the left atrial appendage. The trachea was then cannulated with $1.27-\mathrm{mm}$ diameter tubing and the lungs lavaged with a single 1-ml aliquot of PBS.

\section{Quantification of pulmonary inflammatory cells}

The number of inflammatory cells infiltrating the lung tissue was used to quantify the degree of pulmonary inflammation (Curtis et al., 1994). The excised, perfused lungs were minced and incubated for $30 \mathrm{~min}$ at $37^{\circ} \mathrm{C}$ in a solution containing $1.0 \mathrm{mg} / \mathrm{ml}$ Type IV collagenase and $50 \mathrm{U} / \mathrm{ml}$ DNase I (both from Sigma Chemical Co., St. Louis, MO) in Dulbecco's modified Eagle's medium. After digestion, the tissue was mechanically disrupted by aspirating and expelling it 30 times through a 10-ml plastic syringe (Becton Dickinson, Rutherford, $\mathrm{NJ})$. The cells were centrifuged at $500 \times \mathrm{g}$ for $10 \mathrm{~min}$, after which contaminating erythrocytes were lysed in $\mathrm{NH}_{4} \mathrm{Cl}$. Finally, the cells were filtered through $100-\mu \mathrm{m}$ Nytex filters (Tetko, Switzerland) and counted in a hemocytometer.

\section{Flow cytometric analysis of lymphocyte subtypes}

The single-cell suspensions from collagenase-digested lungs were analyzed using an EPICS Elite apparatus (Coulter Corp., Hialeah, FL), as previously described (Curtis et al., 1994). Cells were stained with the following fluorescein isothiocyanate-labeled monoclonal antibodies obtained from PharMingen (San Diego, CA): 145-2C11, anti-CD3, RM4-5, anti-CD4; 53-6.7, anti-CD8; and RA3-6B2, anti-B220. At least 20,000 events were collected for each sample.

\section{IL-1ra assay}

Concentrations of human IL-1ra in bronchoalveolar lavage fluid were determined by an ELISA (R\&D Systems, Minneapolis, MN). The lower limit of detection of the assay was $0.03 \mathrm{ng} / \mathrm{ml}$. The reactivity of murine IL-1 ra is less than $0.1-0.5 \%$ that of human IL-1ra. Prior to assay, the bronchoalveolar lavage fluid was centrifuged at $8,800 \times g$ for 10 min to remove cells and debris.

\section{Statistical methods}

Data are expressed as the mean \pm SEM. Analysis of variance was used to test for statistically significant differences between groups (StatView 4.0, Abacus Concepts Inc., Berkeley,
CA). If differences were present $(p<0.05)$, pair-wise comparisons were performed using Fisher's protected least significant different (PLSD) test.

\section{RESULTS}

\section{Characterization of incomplete and inactivated adenoviral particles}

The physical and biological properties of the various preparations of adenoviral particles were characterized in several ways. Transmission electron microscopy was used to assess particle integrity. As expected, Ad.RSVIL-Ira appeared as approximately $65-\mathrm{nm}$ icosahedral particles (Fig. 1). Staining with uranyl acetate caused the central cores of the particles to appear electron dense. The incomplete particles of lower buoyant density had a similar icosahedral shape. The core region of some of the particles stained less darkly than the complete particles, presumably due to incomplete packaging of core contents. The viral particles that had been treated with psoralen and ultraviolet light were indistinguishable from untreated adenoviral vectors.

Infectivities of the various adenoviral preparations were measured using a plaque-forming assay on 293 cells. The particle to pfu ratio of intact Ad.RSVIL-I:a varied slightly from preparation to preparation with a mean of $25.9 \pm 9.3$ (SEM, $n=6$ ). The infectivity of incomplete particles was markedly reduced with less that 1 infectious unit detected when up to $3.5 \times 10^{11}$ particles were placed onto 293 cell monolayers. Psoralen/ultraviolet light treatment was very effective at rendering particles noninfectious; less than 1 infectious unit in $3.5 \times 10^{11}$ particles were found following treatment.

As a sensitive indicator of viral genome inactivation, the expression of human IL-1ra was measured 6 days following intratracheal administration of Ad.RSVIL-1 ra. The IL-1 ra concentration in bronchoalveolar lavage fluid obtained from animals receiving $7 \times 10^{10}$ incomplete viral particles was undetectable $(<0.03 \mathrm{ng} / \mathrm{ml} ; n=5)$, while the IL-1ra concentration in bronchoalveolar lavage fluid collected concurrently from animals receiving intact Ad.RSVIL-1ra was $4.4 \pm 0.8 \mathrm{ng} / \mathrm{ml}$ (mean \pm SEM, $n=3$ ). The ability of psoralen/ultraviolet light treatment to inactivate Ad.RSVIL-I ra gene expression was also tested. The concentration of IL-1 ra in bronchoalveolar lavage fluid obtained from animals receiving $7.0 \times 10^{10}$ inactivated viral particles was undetectable $(<0.03 \mathrm{ng} / \mathrm{ml}, n=5)$. Animals receiving intact Ad.RSVIL-1 ra concurrently had 11.0 0.4 $\mathrm{ng} / \mathrm{ml}$ (mean $\pm \mathrm{SEM}, n=5$ ) IL-1ra in their lavage fluid.

We also determined whether incomplete or inactivated particles had lost the ability to express a virus-specific protein, namely the $72-\mathrm{kD}$ E2A gene product. Monolayers of 293 cells were infected with viral particles, and after $24 \mathrm{hr}$ cell lysates were analyzed for E2A antigen by immunoelectrophoresis. We found that lysates from cells infected with intact Ad.RSVILIr a particles contained easily detectable E2A antigen (Fig. 2, lanes 1 and 2). Lysates from cells infected with incomplete or psoralen/ultraviolet light-treated Ad.RSVIL-1 ra particles failed to show a band at $\sim 72 \mathrm{kD}$ under assay conditions that would have revealed E2A antigen at levels down to $1 \%$ of the amount generated by intact viral particles. 


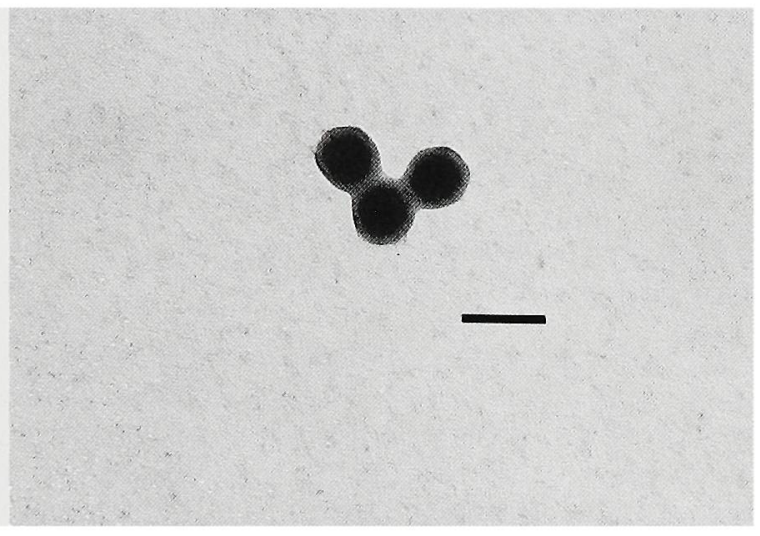

$\mathbf{A}$

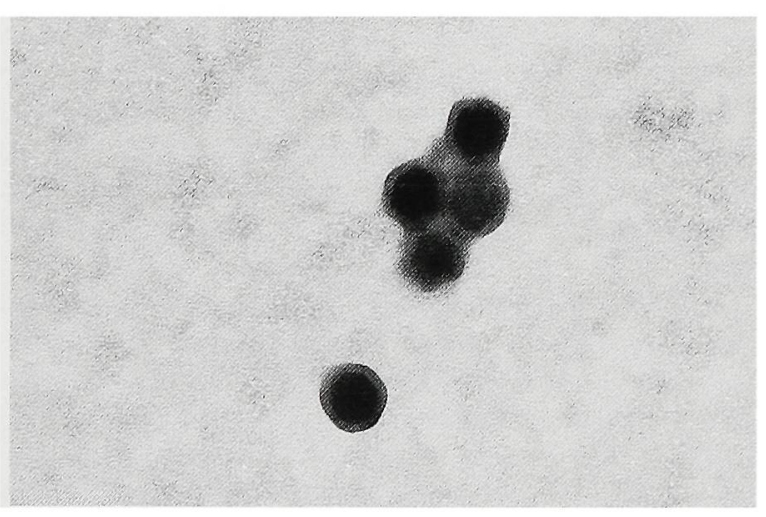

B

C

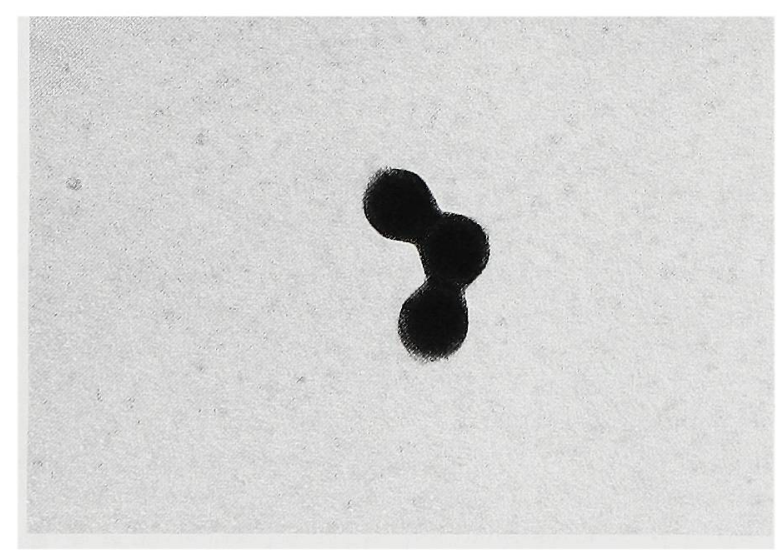

FIG. 1. Electron photomicrographs of adenoviral particles. Intact, incomplete, and inactivated adenoviral preparations were prepared as described in Materials and Methods. After fixation with glutaraldehyde and staining with uranyl acetate, the particles were examined in the transmission electron microscope. A. Intact Ad.RSVIL.1ra particles. B. Incomplete Ad.RSVIL-1ra particles. C. Psoralen/ultraviolet-light-treated Ad.RSVIL-1ra. Bar, $100 \mathrm{~nm}$.

Inflammation induced by intact, incomplete, or inactivated Ad.RSVIL-1 ra

Intratracheal instillation of Ad.RSVIL-1 ra caused a dose-dependent increase in the number of inflammatory cells released from collagenase-digested lungs (Fig. 3). In a previous study,

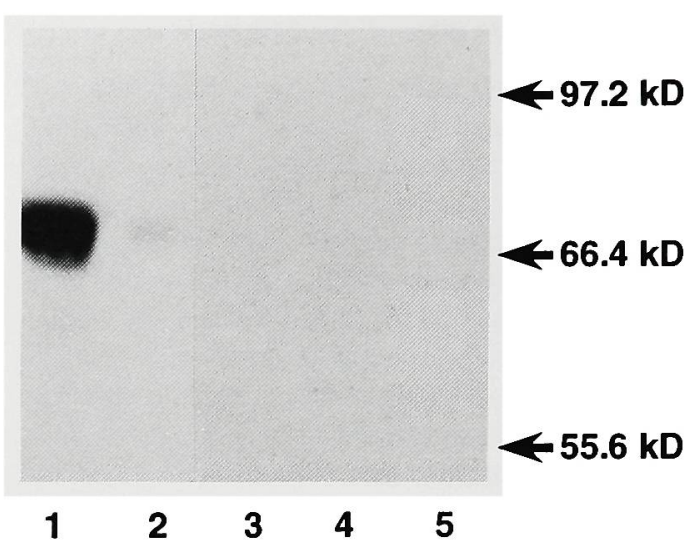

FIG. 2. Immunoelectrophoresis of Ad.RSVIL-1ra-infected 293 cells for adenoviral E2A antigen. Monolayers of 293 cells were incubated with viral particles ( 700 particles/cell). After $24 \mathrm{hr}$, lysates were analyzed by Western blot using a monoclonal antibody against the E2A adenovirus protein. Lane 1, Lysate from $10^{4}$ cells that had been infected with intact Ad.RSVIL-1ra particles; lane 2, same as lane 1 except containing lysate from $10^{3}$ cells; lane 3 , lysate from $10^{5}$ cells exposed to buffer alone; lane 4 , lysate from $10^{5}$ cells exposed to incomplete viral particles; lane 5 , lysate from $10^{5}$ cells exposed to psoralen/ultraviolet light-inactivated Ad.RSVIL-1ra particles. The arrows point out the distances migrated by protein standards.

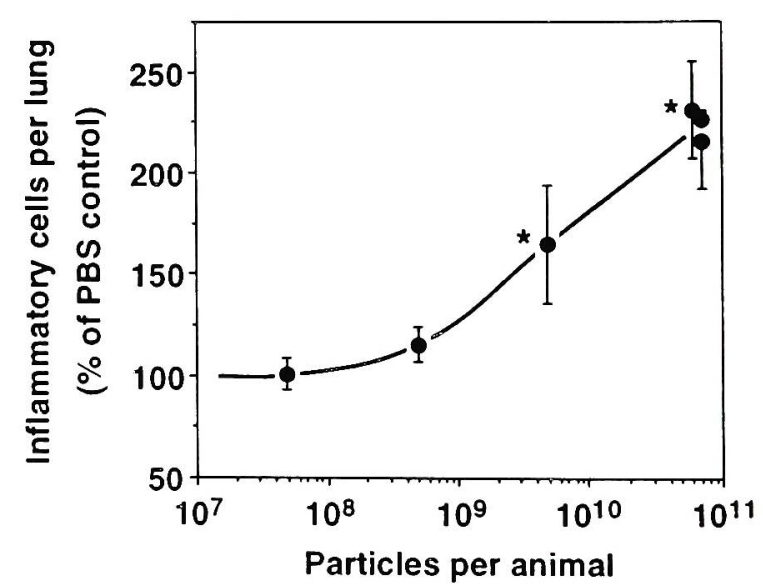

FIG. 3. Pulmonary inflammation caused by intact Ad.RSVIL-1 ra. Anesthetized mice were injected intratracheally with $0.05 \mathrm{ml}$ of PBS alone or containing various concentrations of intact Ad.RSVIL-1ra. After 6 days, the animals were sacrificed, and the number of leukocytes within collagenase-digested lungs were counted. Data are pooled from four separate experiments. Each point represents the mean \pm SEM $(n=3-5$ animals) of the number of inflammatory cells in Ad.RSVIL1ra-treated lungs expressed as the percent of inflammatory cells relative to the number present in the lungs of control animals receiving PBS concurrently. [*indicates numbers of inflammatory cells per lung that are significantly higher $(p<0.05)$ than that of animals receiving PBS.] 
we showed that the increase in inflammatory cells was associated with the histologic appearance of an alveolar infiltrate consisting predominantly of lymphocytes and macrophages (McCoy et al., 1995). The administration of high doses $(7.0 \times$ $10^{10}$ particles/animal) of incomplete particles also caused a statistically significant $(p<0.01)$ increase in lung inflammatory cells relative to animals receiving PBS (Fig. 4). Importantly, there was no difference in the number of lung inflammatory cells released from the lungs of animals receiving intact and incomplete Ad.RSVIL-Ira $(p=0.49, n=4-5)$. The distribution of lymphocytes, monocytes, and neutrophils within the population of lung inflammatory cells was determined for each group of animals by examining cells that had been sedimented onto slides by cytocentrifuge and stained with a modified Wright's stain. We found no significant difference $(p>0.1)$ in the distribution of inflammatory cell types obtained from lungs of animals treated with PBS alone, with intact functional vectors, or with incomplete particles. The percentages of cells from the combined groups were $71.3 \%$ lymphocytes, $22.1 \%$ monocyte/macrophages, and $6.6 \%$ neutrophils.

We also measured the amount of inflammation caused by adenoviral particles that had been previously inactivated by psoralen/ultraviolet light treatment. Similar to the results using incomplete particles, we found no difference in the number of inflammatory cells released from collagenase-digested lungs that had been treated with either intact or inactivated Ad.RSVIL-1 ra particles $(p=0.69, n=5)$. Importantly, both preparations of particles caused a statistically significant increase $(p<0.01)$ in lung inflammatory cells over lungs receiving PBS alone (Fig. 5).

\section{Identification of lymphocyte subsets infiltrating the lungs of animals receiving incomplete or intact Ad.RSVIL-1ra}

Although the total number of inflammatory cells infiltrating the lungs did not differ between animals receiving incomplete

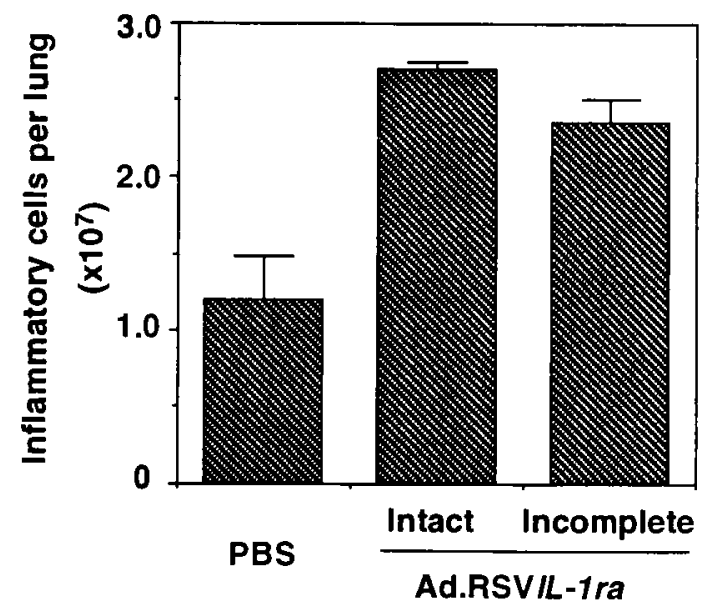

FIG. 4. Comparison of pulmonary inflammation caused by intact and incomplete Ad.RSVIL $=1 \mathrm{ra}$. Anesthetized mice were given $0.05 \mathrm{ml}$ of PBS alone $(n=5)$ or with $7.0 \times 10^{10}$ particles of intact $(n=4)$ or incomplete $(n=5)$ Ad.RSVIL1ra. After 6 days, the animals were sacrificed, and the number of inflammatory cells contained in collagenase-digested lungs were counted. Data represent the mean \pm SEM.

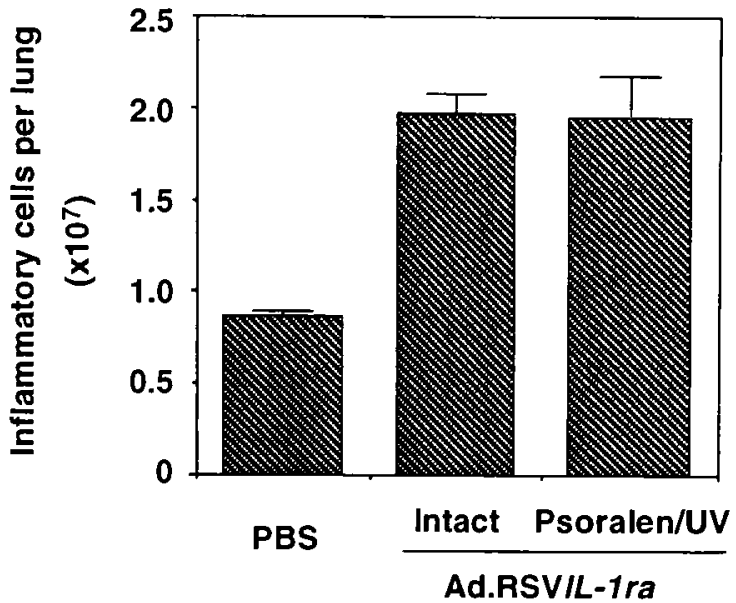

FIG. 5. Comparison of pulmonary inflammation caused by intact and inactivated Ad.RSVIL-1ra. Anesthetized mice were given $0.05 \mathrm{ml}$ of PBS alone or with $7.0 \times 10^{10}$ particles of intact or psoralen/ultraviolet light-inactivated (psoralen/uv) Ad.RSVIL-1ra. After 6 days, the animals were sacrificed, and the number of inflammatory cells contained in collagenase-digested lungs were counted. Data represent the mean $\pm S E M$, $n=5$.

or intact Ad.RSVIL-Ira, we investigated whether the relative proportions of lymphocyte subsets might differ. Accordingly, flow cytometry with fluorescein-labeled antibodies was used to analyze the number of lymphocytes displaying the cell-surface antigens CD3, CD4, CD8, and B220. We found negligible differences in the proportions of lymphocyte subtypes obtained from animals receiving intact or incomplete adenoviral particles (Table 1). A quantitatively small, but statistically significant $(p=0.03)$, increase in the percentage of B cells $(B 220+)$ was seen in animals receiving incomplete viral particles compared to those administered intact Ad.RSVIL-1 ra. No other statistically significant differences were present.

Table 1. Lymphocyte Subsets Within Lungs of Mice INFECTED WITH INCOMPLETE AND INTACT AD.RSVIL-1RA

\begin{tabular}{lccc}
\hline & & \multicolumn{2}{c}{ Ad.RSVIL-1ra } \\
\cline { 3 - 4 } Lymphocyte subtype & PBS & Intact & Incomplete \\
\hline $\mathrm{CD}^{+}$(T cells) & $49 \pm 3$ & $41 \pm 1^{\mathrm{b}}$ & $41 \pm 2^{\mathrm{b}}$ \\
$\mathrm{CD}^{+}$ & $33 \pm 1$ & $27 \pm 1^{\mathrm{b}}$ & $28 \pm 1^{\mathrm{b}}$ \\
$\mathrm{CD}^{+}$ & $14 \pm 2$ & $10 \pm 1$ & $14 \pm 2$ \\
$\mathrm{~B}^{+} 20^{+}$(B cells) & $51 \pm 2$ & $47 \pm 2^{\mathrm{c}}$ & $53 \pm 1^{\mathrm{c}}$ \\
\hline
\end{tabular}

a\% of total lymphocytes.

${ }^{\mathrm{b}} p<0.05$ compared to PBS.

${ }^{c} p=0.03$ comparing intact and incomplete Ad.RSVIL-1ra.

A total of $50 \mu \mathrm{l}$ of PBS alone or containing $4.9 \times 10^{9}$ particles of intact or incomplete Ad.RSVIL-1ra were intratracheally instilled into mice. After 6 days, the animals were sacrificed and their intrapulmonary mononuclear inflammatory cells recovered and analyzed by flow cytometry. Each entry in the table represents the mean $\pm \operatorname{SEM}(n=3)$ of the percent of total lymphocytes stained by the respective antibody. 


\section{DISCUSSION}

Use of adenovirus-based gene therapy vectors has proved to be one of the more efficient, currently available methods for transferring genes to nondividing cells in vivo (Levrero et al., 1991; Rosenfeld et al., 1992; Engelhardt et al., 1993; Zabner et al., 1993). However, a limitation to the use of high doses of adenoviral vectors for the lung has been the development of pulmonary inflammation (Simon et al., 1993; Brody et al., 1994; Crystal et al., 1994; Engelhardt et al., 1994; Yang et al., 1994; Yei et al., 1994). The mechanisms by which adenoviral vectors induce inflammation are likely to be multiple and complex. We chose to approach the problem by examining the contribution of the viral particle itself, independent of its ability to express the genes it contains. We found that the development of pulmonary inflammation in mice receiving adenoviral vectors did not require a functional viral genome.

We used two different methods to generate viral particles that were defective in gene expression. A class of particles are made during adenoviral production in 293 cells that contain an incomplete complement of DNA (Burlingham et al., 1974; Toth et al., 1982; Morin and Boulanger, 1984). These particles can be separated from complete virions by sedimentation on $\mathrm{CsCl}$ gradients due to their lighter buoyant densities. We found that incomplete particles of Ad.RSVIL-I ra retained their icosahedral shape, but were unable to replicate or express the E2A adenoviral protein in 293 cells. Importantly, these particles failed to induce expression of human IL-1 ra when delivered to mouse lungs. It is highly unlikely that these incomplete particles could induce in vivo synthesis of adenovirus-specific genes for two reasons. First, the adenoviral genome, which is a single, linear, double-stranded DNA molecule, is packaged into the viral capsid with its left end being incorporated first (Hammarskjold and Winberg, 1980). Because the IL-1ra transgene is located very close to the left end of the adenoviral genome (replaces map units 1-9), all adenovirus-specific structural genes are therefore located to the right of it. For this reason, incomplete particles that did not induce IL-1ra expression in mouse lungs could not have packaged and expressed virus-specific genes without producing IL-1ra. Further evidence that the incomplete particles were deficient in gene expression was our observation that they failed to produce E2A in the permissive 293 cell line.

Although the adenoviral particles of lighter buoyant density retained their capsid geometry when viewed in transmission electron micrographs, it is known that some of their structural proteins are incompletely assembled or processed (Morin and Boulanger, 1984). The final steps of viral assembly involve proteolytic cleavage of capsid proteins, a process that is not necessarily complete in the lighter particles. Therefore, it is possible that these incomplete particles do not precisely duplicate the inflammatory properties of intact, infectious virions. Accordingly, we used a second method, namely cross-linking of viral DNA by exposure to ultraviolet light in the presence of 8-methoxypsoralen, to generate particles having defective gene expression. Previous studies by others have shown that treatment of adenoviruses with psoralen/ultraviolet light blocks viral replication but leaves intact their ability to enter target cells and induce endosomolysis (Cotten et al., 1994). These studies also have shown that viral gene transcription, as measured by reverse transcriptase-polymerase chain reaction, was prevented by psoralen/ultraviolet light treatment. In agreement, we found that human IL-1ra levels were undetectable in bronchoalveolar lavage fluid from mice receiving psoralen/ultraviolet light-inactivated Ad.RSVIL-1 ra. Because DNA cross-links formed by psoralen/ultraviolet light treatment are evenly distributed along the adenoviral genome (Cotten et al., 1994), it is very unlikely that the inactivated Ad.RSVIL-Ira could express substantial levels of virus-specific genes without also expressing similar levels of IL-1 ra. This conclusion is further supported by our observation that inactivated particles did not produce E2A in cultured 293 cells.

Despite these considerations, we cannot exclude the possibility that a small number of competent viral particles were contained in the preparations of incomplete or inactivated Ad.RSVIL-1 ra. However, the extent of inflammation seen in the animals receiving these preparations is very unlikely to be due to residual active particles. The IL-1ra ELISA has a lower limit of detection of $0.03 \mathrm{ng} / \mathrm{ml}$. Because IL-1ra levels in mice receiving intact, active Ad.RSVIL-Ira ranged from 4.4 to 11.0 $\mathrm{ng} / \mathrm{ml}$, the maximal amount of residual gene expression in animals receiving defective virus was less than $0.3-0.7 \%$ of the level expressed in animals receiving intact virus. The relationship between the dose of intact Ad.RSVIL-1 ra and the number of lung inflammatory cells (Fig. 3) shows that animals receiving less than $10^{9}$ intact particles do not develop increased levels of pulmonary inflammatory cells. Therefore, even if $0.3-0.7 \%$ of the particles contained in the inocula of incomplete or inactivated vectors were functionally active, there was an insufficient number of competent particles to account for the amount of inflammation observed (Figs. 4 and 5).

In addition to finding no difference in the number of inflammatory cells within the lungs of animals receiving intact, incomplete, or inactive viral particles, we also found no significant differences in the distribution of inflammatory cell types. Lymphocytes and macrophages increased proportionally, with neutrophils remaining the minor component. These findings correlate well with published descriptions of lung histology following adenovirus administration (Ginsberg et al., 1991; Prince et al., 1993; Simon et al., 1993; Brody et al., 1994; Engelhardt et al., 1994; Yang et al., 1994; Yei et al., 1994). Our analysis of lymphocyte subsets showed that the percentage of lymphocytes that were $\mathrm{CD} 8^{+}$was similar between active and incomplete viral particles. One stimulus that is known to initiate a cytotoxic $T$ cell response is the display of endogenously synthesized viral peptides on the surface of infected cells in conjunction with class I major histocompatibility antigens. However, the presence of a $\mathrm{CD} 8^{+}$infiltrate in mice that received incomplete particles does not imply that viral gene synthesis had taken place. In fact, there is another class I-dependent pathway leading to $\mathrm{CD} 8^{+}$cell accumulation that does not require synthesis of foreign proteins (Kaufmann, 1988). This alternative pathway, which involves the uptake and processing of exogenous foreign material by antigen-presenting cells, may be responsible for the $\mathrm{CD} 8^{+}$infiltrate seen in our animals.

Our finding that high doses of expression-defective adenoviral particles can induce inflammation has several important implications regarding the use of adenoviral vectors in pulmonary-directed gene therapy. First, manipulations of the adenoviral genome that limit expression of virus-specific genes will 
not prevent lung inflammation when high doses of virus are used. The dose-response curve for airway delivery of genes by adenoviral vectors is uncertain. Zabner and colleagues instilled an adenoviral vector containing the cystic fibrosis transmembrane conductance regulator (CFTR) cDNA into the noses of cystic fibrosis patients (Zabner et al., 1993). They reported that exposure of $0.5 \mathrm{~cm}^{2}$ of nasal epithelium to as low as $10^{6}$ infectious units temporarily normalized transepithelial electrophysiology without causing inflammation. Crystal et al. reported that airway administration of $2 \times 10^{6}$ pfu of a CFTR-containing adenoviral vector induced expression of CFTR protein in bronchial epithelial cells (Crystal et al., 1994). However, other patients participating in this study failed to demonstrate CFTR protein in bronchial lining cells despite receiving a 10-fold higher dose. Furthermore, a patient who received the highest dose of virus in the study, $2 \times 10^{9} \mathrm{pfu}$, acutely developed pulmonary inflammation.

Other investigators have reported that adenoviral vectors have a low efficiency for transferring genes into intact human airways. In particular, Grubb and colleagues exposed excised segments of human bronchi to adenoviral vectors and measured the amount of transgene expression (Grubb et al., 1994). They found only low levels of gene expression despite using up to $4 \times 10^{11} \mathrm{pfu} / \mathrm{ml}$ of vector. The only significant expression occurred within basal epithelial cells in areas of the airway that had been previously abraded. In parallel experiments, these investigators found a similarly low efficiency of gene transfer in mice. Of considerable concern is our observation that the higher doses of vector used by Grubb and colleagues are in the same range or higher than those that we found induced inflammation in mice. Thus, the inflammatory response to the viral particle itself might present a dose-limiting toxicity.

In summary, we found that high doses of adenoviral vectors can induce pulmonary inflammation, independent of their capacity to express the genes which they contain. This result suggests that manipulation of the adenoviral genome to limit expression of virus-specific genes will not prevent lung inflammation if high doses of adenovirus vectors are required to achieve therapeutic gene transfer. There will likely be an upper limit to the viral dose, above which inflammation will be induced solely by the presence of the viral proteins contained within the inoculum. The successful use of adenoviral vectors for pulmonary gene therapy will depend upon their ability to achieve adequate gene transfer at doses below those that induce particle-dependent inflammation. Alternatively, methods will have to be developed that block the inflammatory response generated by the viral capsid proteins.

\section{ACKNOWLEDGMENTS}

This work was supported in parts by grants from the National Institutes of Health (HL46487, DK47968, AR20557, and HD33531), a Research Training Fellowship from the American Lung Association of Michigan (R.D.M.), and a fellowship from the Roy J. Carver Charitable Trust (B.L.D.). The investigators would like to thank Kunjoonjamma Cherian for assisting in the preparation of the adenoviral particles and Susan B. Shollenberger for general technical assistance.

\section{REFERENCES}

BRODY, S.L., METZGER, M., SANEL, C., ROSENFELD, M.A., and CRYSTAL, R.G. (1994). Acute responses of non-human primates to airway delivery of an adenovirus containing the human cystic fibrosis transmembrane conductance regulator cDNA. Hum. Gene Ther. 5, 821-836.

BURLINGHAM, B.T., BROWN, D.T., and DOERFLER, W. (1974). Incomplete particle of adenovirus. I. Characteristics of the DNA associated with incomplete adenovirions of types 2 and 12 . Virology $60,419-430$

COTTEN, M., WAAGNER, E., ZATLOUKAL, K., PHILLIPS, S., CURIEL, D.T., and BIRNSTIEL, M.L. (1992). High-efficiency receptor-mediated delivery of small and large (48 kilobase) gene constructs using the endosome-disruption activity of defective or chemically inactivated adenovirus particles. Proc. Natl. Acad. Sci. USA 89, 6094-6098.

COTTEN, M., SALTIK, M., KURSA, M., WAGNER, E., MAASS, G., and BIRNSTIEL, M.L. (1994). Psoralen treatment of adenovirus particles eliminates virus replication and transcription while maintaining the endosomolytic activity of the virus capsid. Virology 205, 254-261.

CRYSTAL, R.G., MCELVANEY, N.G., ROSENFELD, M.A., CHU, C., MASTRANGELI, A., HAY, J.G., BRODY, S.L., JAFFE, H.A., EISSA, N.T., and DANEL, C. (1994). Administration of an adenovirus containing the human CFTR cDNA to the respiratory tract of individuals with cystic fibrosis. Nat. Genet. 8, 42-50.

CURTIS, J.L., HUFFNAGLE, G.B., CHEN, G., WARNOCK, M.L., GYETKO, M.R., McDONALD, R.A., SCOTT, P.J., and TOEWS, G.B. (1994). Experimental murine pulmonary cryptococcosis. Differences in pulmonary inflammation and lymphocyte recruitment induced by two encapsulated strains of cryptococcus neoformans. Lab. Invest. 71, 113-126.

ENGELHARDT, J.E., YANG, Y., STRATFORD-PERRICAUDET, L.D., ALLEN, E.D., KOZARSKY, K., PERRICAUDET, M., YANKASKAS, J.R., and WILSON, J.M. (1993). Direct gene transfer of human CFTR into human bronchial epithelial of xenografts wiht E1-deleted adenoviruses. Nat. Genet. 4, 27-34.

ENGELHARDT, J.F., LITZKY, I,, and WILSON, J.M. (1994). Prolonged transgene expression in cotton rat lung with recombinant adenoviruses defective in E2a. Hum. Gene Ther. 5, 1217-1229.

GINSBERG, H.S., MOLDAWER,L.L., SEHGAL, P.B., REDINGTON, M., KILIAN, P.L., CHANOCK, R.M., and PRINCE, G.A. (1991). A mouse model for investigating the molecular pathogenesis of adenovirus pneumonia. Proc. Nat. Acad. Sci. USA 88, 1651-1655.

GRAHAM, F.L., SMILEY, J., RUSSELL, W.C., and NAIRN, R. (1977). Characteristics of a human cell line transformed by DNA from human adenovirus type 5. J. Gen. Virol. 36, 59-74.

GRUBB, G.R., J., R.R., YE, H., YANKASKAS, R.R., VICK, R.N., ENGELHARDT, J.F., WILSON, J.M., JOHNSON, L.G., and BOUCHER, R.C. (1994). Inefficient gene transfer by adenovirus vector to cystic fibrosis airway epithelia on mice and humans. Nature 371, 802-806.

HAMMARSKJOLD, M., and WINBERG, G. (1980). Encapsidation of adenovirus 16 DNA is directed by a small DNA sequence at the left end of the genome. Cell 20, 787-795.

HUDSON, J.B., GRAHAM, E.A., CHAN, G.C., and TOWERS, G.H.N. (1985). Differential effects of photoactive furanyl comounds on virus functions. Photochem. Photobiol. 42, 523-528.

KAUFMANN, S.H. (1988). CO8 ${ }^{+}$T lymphocytes in intracellular microbial infections. Immunol. Today 9, 168-174.

LAEMMLI, U.K. (1979). sembly of the head of bacteriophage T4. Nature 227, 680-685.

LEVRERO, M., BARBAN, V., MANTECA, S., BALLAY, A., BALSAMO, C., AVANTAGGIATI, M.L., NATOLI, G., SKELLEKENS, 
H., TIOLLAIS, P., and PERRICAUDET, M. (1991). Defective and nondefective adenovirus vectors for expressing foreign genes in vitro and in vivo. Gene 101, 195-202.

MCCOY, R.D., DAVIDSON, B.L., ROESSLER, B.J., HUFFNAGLE, G.B., and SIMON, R.H. (1995). Expression of human interleukin1 receptor antagonist in mouse lungs using a recombinant adenovirus: Effects on vector-induced inflammation. Gene Therapy 2, $437-442$.

MORIN, N., and BOULANGER, P. (1984). Morphogenesis of human adenovirus type 2: Sequence of entry of proteins into previral and viral particles. Virology 136, 153-167.

PRINCE, G.A., PORTER, D.D., JENSON, A.B., HORSWOOD, R.L., CHANOCK, R.M., and GINSBERG, H.S. (1993). Pathogenesis of adenovirus type 5 pneumonia in cotton rats (Sigmodon hispidus). J. Virol. 67, 101-111.

REICH, N.C., SARNOW, P., DUPREY, E., and LEVINE, A.J. (1983). Monoclonal antibodies which recognize native and denatured forms of the adenovirus DNA-binding protein. Virology 128, 480-484.

ROESSLER, B.J., HARTMAN, J.W., VALLANCE, D.K., LATTA, J.M., JANICH, S.L., and DAVIDSON, B.L. (1995). Inhibition of IL1 induced effects in synoviocytes transduced with the human IL-1 receptor antagonist cDNA using an adenoviral vector. Hum. Gene Ther. 6, 307-316.

ROSENFELD, M.A., YOSHIMURA, K., TRAPNELL, B.C., YONEYAMA, K., ROSENTHAL, E.R., DALEMANS, W., FUKAYAMA, M., BARGON, J., STIER, L.E., STRATFORD-PERRICAUDET, L., PERRICAUDET, J., GUGGINO, W.B., LECOCQ, J.P., and CRYSTAL, R.G. (1992). In vivo transfer of the human cystic fibrosis transmembrane conductance regulator gene to the airway epithelium. Cell 68, 143-155.

SIMON, R.H., ENGELHARDT, J.F., YANG, Y., ZEPEDA, M., WEBER, P.S., GROSSMAN, M., and WLSON, J.M. (1993). Adenovirus-mediated transfer of the CFTR gene to lung of nonhuman primates: toxicity study. Hum Gene Ther. 4, 771-780.

TOTH, M., TARODI, B., and BELADI, I. (1982). Preparative separa- tion of intact incomplete adenovirus type 2 particles. Acta Virol. 26, 217-220.

YANG, Y., NUNES, F.A., BERENCSI, K., GONCZOL, E., ENGELHARDT, J.F., and WILSON, J.M. (1994). Inactivation of E2a in recombinant adenoviruses limits cellular immunity and improves the prospect for gene therapy of cystic fibrosis. Nat. Genet. 7, 363-369.

YANG, Y., LI, Q., ERTL, H.C., and WILSON, J.M. (1995). Cellular and humoral immune responses to viral antigens create barriers to lung-directed gene therapy with recombinant adenoviruses. J. Virol. 69, 2004-2015.

YEI, S., MITTEREDER, N., WERT, S., WHITSETT, J.A., WILMOTT, R.W., and TRAPNELL, B.C. (1994). In vivo evaluation of the safety of adenovirus-mediated transfer of the human cystic fibrosis transmembrane conductance regulator cDNA to the lung. Hum. Gene Ther. 5, 731-744.

ZABNER, J., COUTURE, L.A., GREGORY, R.J., GRAHAM, S.M., SMITH, A.E., and WELSH, M.J. (1993). Adenovirus-mediated gene transfer transiently corrects the chloride transport defect in nasal epithelia of patients with cystic fibrosis. Cell 75, 207-216.

ZABNER, J., PETERSEN, D.M., PUGA, A.P., GRAHAM, S.M., COUTURE, L.A., KEYES, L.D., LUKASON, M.J., ST. GEORGE, J., GREGORY, R.J., SMITH, A.E., and WELSH, M.J. (1994). Safety and efficacy of repetitive adenovirus-mediated transfer of CFTR cDNA to airway epithelia of primates and cotton rats. Nat. Genet. 6 , $75-83$.

Address reprint requests to: Dr. Richard H. Simon University of Michigan Medical Center 3916 Taubman Center, Box 0360 Ann Arbor, MI 48109-0360

Received for publication February 13, 1995; accepted after revision July 31, 1995. 


\section{This article has been cited by:}

1. D L Lichtenstein, J F Spencer, K Doronin, D Patra, J M Meyer, E V Shashkova, M Kuppuswamy, D Dhar, M A Thomas, A E Tollefson, L A Zumstein, W S M Wold, K Toth. 2009. An acute toxicology study with INGN 007, an oncolytic adenovirus vector, in mice and permissive Syrian hamsters; comparisons with wild-type Ad5 and a replication-defective adenovirus vector. Cancer Gene Therapy . [CrossRef]

2. Ping Chen, Melissa Hamilton, Charles A Thomas, Kurt Kroeger, Miguel Carrion, Randall S MacGill, Peter Gehlbach, Douglas E Brough, Lisa L Wei, C Richter King, Joseph T Bruder. 2009. Persistent Expression of PEDF in the Eye Using High-capacity Adenovectors. Molecular Therapy 16:12, 1986-1994. [CrossRef]

3. K Benihoud, S Esselin, D Descamps, B Jullienne, B Salone, P Bobé, D Bonardelle, E Connault, P Opolon, I Saggio, M Perricaudet. 2007. Respective roles of TNF- $\alpha$ and IL- 6 in the immune response-elicited by adenovirus-mediated gene transfer in mice. Gene Therapy 14:6, 533-544. [CrossRef]

4. Leslie J. Crofford, Kevin T. McDonagh, Sutang Guo, Hemal Mehta, Huimin Bian, Lilli M. Petruzelli, Blake J. Roessler. 2005. Adenovirus binding to cultured synoviocytes triggers signaling through MAPK pathways and induces expression of cyclooxygenase-2. The Journal of Gene Medicine 7:3, 288-296. [CrossRef]

5. Dr. Daniel A. Muruve . 2004. The Innate Immune Response to Adenovirus VectorsThe Innate Immune Response to Adenovirus Vectors. Human Gene Therapy 15:12, 1157-1166. [Abstract] [PDF] [PDF Plus]

6. Christoph Esslinger, Pedro Romero , H. Robson MacDonald . 2002. Efficient Transduction of Dendritic Cells and Induction of a T-Cell Response by Third-Generation LentivectorsEfficient Transduction of Dendritic Cells and Induction of a T-Cell Response by Third-Generation Lentivectors. Human Gene Therapy 13:9, 1091-1100. [Abstract] [PDF] [PDF Plus]

7. Gloria P. Bowen, Stephanie L. Borgland, Mindy Lam, Towia A. Libermann, Norman C.W. Wong, Daniel A. Muruve . 2002. Adenovirus Vector-Induced Inflammation: Capsid-Dependent Induction of the C-C Chemokine RANTES Requires NF- $\varkappa$ BAdenovirus Vector-Induced Inflammation: Capsid-Dependent Induction of the C-C Chemokine RANTES Requires NF- $\varkappa$ B. Human Gene Therapy 13:3, 367-379. [Abstract] [PDF] [PDF Plus]

8. Karim Benihoud, Barbara Salone, Stephanie Esselin, Paule Opolon, Valeria Poli, Monica Di Giovine, Michel Perricaudet, Isabella Saggio. 2000. The role of IL-6 in the inflammatory and humoral response to adenoviral vectors. The Journal of Gene Medicine 2:3, 194-203. [CrossRef]

9. Daniel A. Muruve, Melissa J. Barnes, Isaac E. Stillman , Towia A. Libermann . 1999. Adenoviral Gene Therapy Leads to Rapid Induction of Multiple Chemokines and Acute Neutrophil-Dependent Hepatic Injury in VivoAdenoviral Gene Therapy Leads to Rapid Induction of Multiple Chemokines and Acute Neutrophil-Dependent Hepatic Injury in Vivo. Human Gene Therapy 10:6, 965-976. [Abstract] [PDF] [PDF Plus]

10. Theodore J. Standiford, Jodi M. Wilkowski, Thomas H. Sisson, Noboru Hattori, Borna Mehrad, Kathy A. Bucknell , Thomas A. Moore . 1999. Intrapulmonary Tumor Necrosis Factor Gene Therapy Increases Bacterial Clearance and Survival in Murine Gram-Negative PneumoniaIntrapulmonary Tumor Necrosis Factor Gene Therapy Increases Bacterial Clearance and Survival in Murine Gram-Negative Pneumonia. Human Gene Therapy 10:6, 899-909. [Abstract] [PDF] [PDF Plus]

11. John H. Lee, Joseph Zabner, Michael J. Welsh . 1999. Delivery of an Adenovirus Vector in a Calcium Phosphate Coprecipitate Enhances the Therapeutic Index of Gene Transfer to Airway EpitheliaDelivery of an Adenovirus Vector in a Calcium Phosphate Coprecipitate Enhances the Therapeutic Index of Gene Transfer to Airway Epithelia. Human Gene Therapy 10:4, 603-613. [Abstract] [PDF] [PDF Plus]

12. James Brauker, Gloria H. Frost, Varavani Dwarki, Tarlochan Nijjar, Richard Chin, Victoria Carr-Brendel, Carol Jasunas, Debra Hodgett, Wendy Stone, Lawrence K. Cohen, Robert C. Johnson. 1998. Sustained Expression of High Levels of Human Factor IX from Human Cells Implanted within an Immunoisolation Device into Athymic RodentsSustained Expression of High Levels of Human Factor IX from Human Cells Implanted within an Immunoisolation Device into Athymic Rodents. Human Gene Therapy 9:6, 879-888. [Abstract] [PDF] [PDF Plus]

13. Hideaki Kagami, Jane C. Atkinson, Suzanne M. Michalek, Beverly Handelman, Shawn Yu, Bruce J. Baum, Brian O'Connell. 1998. Repetitive Adenovirus Administration to the Parotid Gland: Role of Immunological Barriers and Induction of Oral ToleranceRepetitive Adenovirus Administration to the Parotid Gland: Role of Immunological Barriers and Induction of Oral Tolerance. Human Gene Therapy 9:3, 305-313. [Abstract] [PDF] [PDF Plus] 
14. Forrest K. Ferrari, Xiao Xiao, Doug Mccarty, Richard J. Samulski. 1997. New developments in the generation of Ad-free, high-titer rAAV gene therapy vectors. Nature Medicine 3:11, 1295-1297. [CrossRef]

15. Antoine Lafont, Gervaise Loirand, Pierre Pacaud, Françoise Vilde, Patricia Lemarchand, Denis Escande. 1997. Vasomotor Dysfunction Early after Exposure of Normal Rabbit Arteries to an Adenoviral VectorVasomotor Dysfunction Early after Exposure of Normal Rabbit Arteries to an Adenoviral Vector. Human Gene Therapy 8:9, 1033-1040. [Abstract] [PDF] [PDF Plus]

16. Paul B. McCray, Jr., Guoshun Wang, Joel N. Kline, Joseph Zabner, Sunil Chada, Doug J. Jolly, Steven M. W. Chang, Beverly L. Davidson. 1997. Alveolar Macrophages Inhibit Retrovirus-Mediated Gene Transfer to Airway EpitheliaAlveolar Macrophages Inhibit Retrovirus-Mediated Gene Transfer to Airway Epithelia. Human Gene Therapy 8:9, 1087-1093. [Abstract] [PDF] [PDF Plus]

17. Wim T. J. M. C. Hermens, Joost Verhaagen. 1997. Adenoviral Vector-Mediated Gene Expression in the Nervous System of Immunocompetent Wistar and T Cell-Deficient nude Rats: Preferential Survival of Transduced Astroglial Cells in nude RatsAdenoviral Vector-Mediated Gene Expression in the Nervous System of Immunocompetent Wistar and T Cell-Deficient nude Rats: Preferential Survival of Transduced Astroglial Cells in nude Rats. Human Gene Therapy 8:9, 1049-1063. [Abstract] [PDF] [PDF Plus]

18. Margo R. Adesanya, Robert S. Redman, Bruce J. Baum, Brian C. O'Connell. 1996. Immediate Inflammatory Responses to Adenovirus-Mediated Gene Transfer in Rat Salivary GlandsImmediate Inflammatory Responses to Adenovirus-Mediated Gene Transfer in Rat Salivary Glands. Human Gene Therapy 7:9, 1085-1093. [Abstract] [PDF] [PDF Plus] 